\begin{tabular}{l|l|l|l} 
& $=$ & $7^{\text {th }}$ CONGIC & Blucher Design Proceedings \\
$7^{\text {th }}$ CIDI & $\begin{array}{l}7^{\text {th }} \text { Information Design } \\
\text { International Conference }\end{array}$ & $\begin{array}{l}7^{\text {th }} \text { Information Design } \\
\text { Student Conference }\end{array}$ & $\begin{array}{l}\text { Setembro, 2015 }- \text { num. 2, vol.2 } \\
\text { proceedings.blucher.com.br }\end{array}$
\end{tabular}

\title{
Focus group reading of a sequential narrative involving the representation of time
}

\author{
Eva Rolim Miranda
}

\begin{abstract}
representação temporal, processo de leitura, grupo focal
Neste artigo apresentaremos uma parte da pesquisa de Miranda (2013) que desenvolveu um estudo transcultural à partir de um protocolo de pesquisa composto de seis fases, as quarto primeiras dedicadas à produção de uma sequencia narrativa por participantes franceses : adultos especialistas, adultos nãoespecialistas e dois grupos de crianças. Precisamente nos exploraremos as seçoes de focus group com participantes brasileiros 512 estudantes em Design e 1é estudantes em Turismo) tecendo considerações sobre as dificuldades no momento da leitura que tiveram origem no processo de produção do desenho.
\end{abstract}

time representation, reading process, focus group

In this paper we present part of a research conducted by Miranda (2013). This was a transcultural study, developed from a research protocol composed of six phases. Phases 1-4 were dedicated to the production of a narrative sequence by French participants: specialist adults, nonspecialist adults and two groups of children. We then explored the focus group sessions with Brazilian participants (12 design students and 12 tourism students), examining the reading difficulties encountered and which had originated during the process of producing the drawings.

\section{Introduction}

In order to investigate sequential representation, and more particularly, the representation of time, we conducted an experimental research study (Miranda, 2013) aiming to understand the strategies of representation and the manners in which these representations either help or hinder the reading process. Several previous studies (Coutinho, 1998; Twyman, 1985; Dondis, 1997; Trumbo, 1999; Seels, 1994 and Miranda, 2004, 2006) have linked drawing capacities to interpretative abilities. The key to successful sequential representation is how to manage the representation of time appropriately, and yet, few studies have been devoted to this specific topic.

For our research, we constructed a transcultural experimental protocol with 40 participants divided into four French groups: Parisian children (12), Lille Children (10), specialist adults (8) and nonspecialist adults (10). The specialist group was composed of designers, and the nonspecialist of adults with no professional skills in creating images. Our protocol contained six different phases. Phases 1 to 4 were devoted to producing a drawing based on the same narrative: "Yesterday was Thomas' birthday. Today he is playing with his new toys while his mother prepares breakfast. They are both eagerly waiting for Thomas' father and brother to arrive tomorrow ". Phases 5 to 6 were dedicated to the ranking of drawings based on the best communicational potential. The results presented herein are based on Phase 6, which consisted

E. R. Miranda. 2015. Focus group reading of a sequential narrative involving the representation of time. In: C. G. Spinillo; L. M. Fadel; V. T. Souto; T. B. P. Silva \& R. J. Camara (Eds). Anais [Oral] do $7^{\circ}$ Congresso Internacional de Design da Informação/Proceedings [Oral] of the 7th Information Design International Conference | CIDI 2015 [Blucher Design Proceedings, num.2, vol.2]. São Paulo: Blucher, 2015. ISSN 2318-6968, ISBN: 978-85-8039-122-0. DOI 10.5151/designpro-CIDI2015-cidi_96 
of a focus group of Brazilian participants (12 design students and 12 tourism students) who read the drawings with the aim of reconstructing the initial narrative.

The processes involved in producing and reading a sequential narrative are very complex, and producers must make representational choices on items such as the style of illustration, colours, size, scale, spatial organization and reading directions as well as selecting and hierarchizing the information. Users on the other hand, when reading these kinds of graphic communicational artefacts - GCAs, ${ }^{1}$, need to understand the pictorial representation and reading direction, identify the steps and transpose them into a real-life situation, sometimes articulating a two dimensional representation into actual width, length and depth, thus allowing the user to build a narrative process.

\section{Narrative Process}

Building a sequence starts by separating the narrative as a whole into separate portions, placing one portion of information after another, with or without the use of boxes. The sequence of these portions already constitutes a sequence of images, although in itself not a narrative. In order to obtain a narrative, the portions must share a common theme. According to Groensteen (1999), a random combination of images responds to a different logic, but only one sequence that shares a common theme is able to confront the requirements of a narrative.

Sometimes even sequential images as part of a narrative are not recognized as such. Recognising the sequence of an image is related to the reading process. It is not only important to know and understand the agreements and conventions that go beyond the sequence of images, but also what each portion represents (Sohet, 2007). Before establishing a sequence, the narrative images must meet four criteria in order to create a narrative process. First, there should be a figurative level for representational purposes, followed by a correlation level where images are not only juxtaposed, but have a clear link thus forming a composition. There should also be a level of consecution, based on spatial control, in which temporality may be expressed. And finally, a level of entanglement, where temporal and spatial articulations are capable of producing a plot of actions. According to Cook (1981, p.62), a single image is not able to convey the passage of time.

Several images are required to conduct a narrative, with a specific reading direction. The construction of a narrative sequence must consider several graphic parameters, such as the choice of components, size and the events to be represented. All this information needs to be organised so as to ensure that the user/reader will be able to follow the reading direction thought out by the producer, and thus understand the information. In printed GCAs the producer must also consider the fact that reading is carried out on several levels. First, the user obtains a global view and then focuses on each portion of the narrative so as to interpret each one, as we observed in our focus group.

The main objective of the focus group phase was based on a panel composed of four drawings, for which participants worked in groups of three to reconstruct the initial narrative "Yesterday was Thomas' birthday. Today he is playing with his new toys while his mother prepares breakfast. They are both eagerly waiting for Thomas' father and brother to arrive tomorrow ". They also attempted to identify any representational problems or graphic strategies that helped them to achieve a better understanding. During the sessions they were free to select

\footnotetext{
${ }^{1}$ Graphic Communicational Artifacts - GCAs are produced by professionals specialised in producing images and are used by people of all ages and categories ranging from children to adults. They may be applied to assembling toys, recipes, taking medication, furniture instructions, etc. They cover several areas, categories, products and situations. They contain complex information and in order to read and understand them, users must comprehend graphical representation and schematic elements such as arrows, lines, dots, phylacteries, onomatopoeia as well as the reading direction. Often users need to know how to transpose two-dimensional information into three-dimensional, articulating the length, width, depth of objects that have been represented in print or on a screen.
}

Anais [Oral] do 7ํㅡㄹ Congresso Internacional de Design da Informação | CIDI 2015

Proceedings [Oral] of the 7th Information Design International Conference / IDIC 2015 
either a group or individual version of the narrative.

\section{Focus group}

\section{Panel 1}

Figure 1 \& 2: Panel 1 composition, drawing by Lille children - Session 1 and drawing by Parisian children - Session 2.
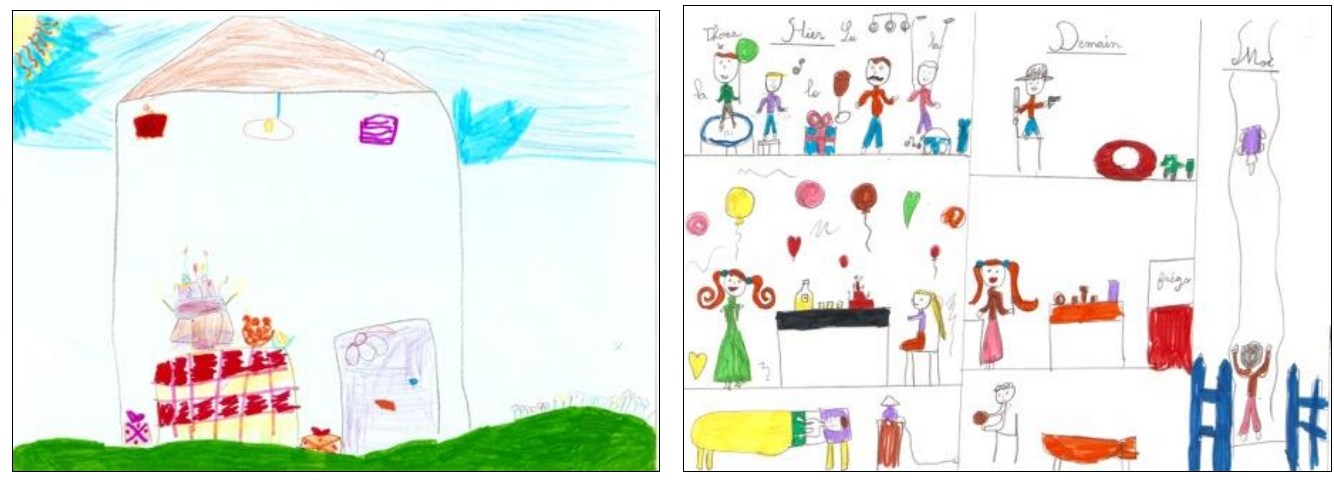

Figure 3 \& 4: Panel 1 composition, drawing by specialists - Session 3. and drawing by non-specialists - Session 4.

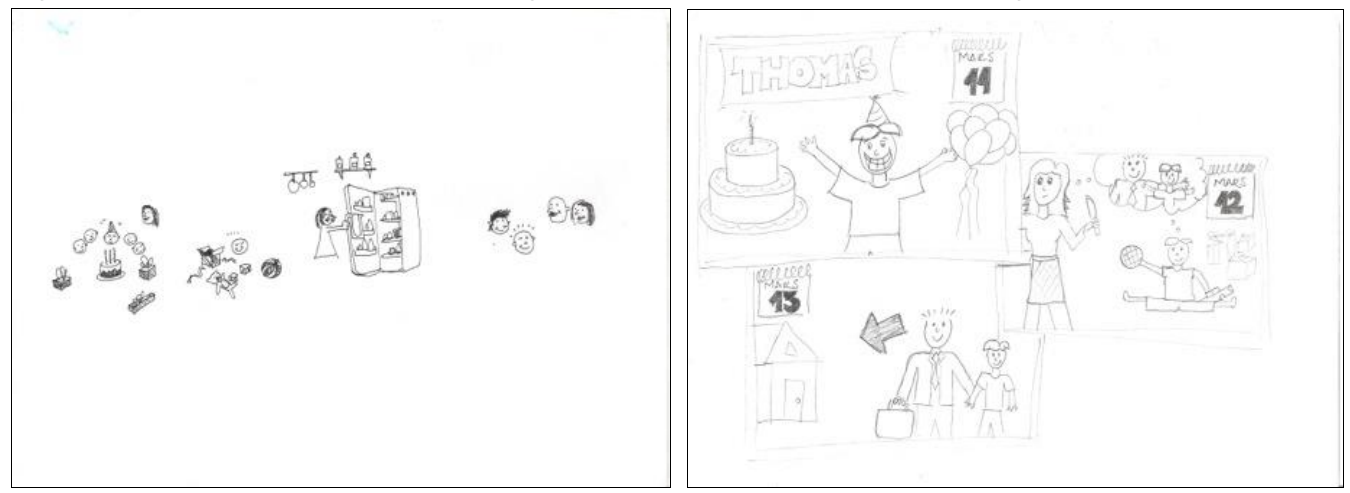

Specialist focus group 1

Our initial observation was that the birthday scene was understood by all three participants. However, following this, interpretations regarding the narrative took on several directions.

Participants did not understand that there were three temporal dimensions in the narrative (yesterday, today and tomorrow), and only identified two: present and future. Although this was not made clear, they referred to the future by indicating the existence of the present, as demonstrated by participant A: "The next day his father arrives", and participant C: "And the next day he goes to his father's home."

The drawing contained very little graphic representation that distinguished Thomas' brother from his father, or indeed Thomas from his brother. Consequently, participants failed to understand that there were in fact four characters in the drawings, and they only managed to identify three: the mother, the father and Thomas. No reference was made to the brother (Figs.34).Another possibility for this is that the producers had given insufficient emphasis to these components and as the participants failed to understand them, they therefore spent less time focusing on them.

Simultaneous actions were also not mentioned (Thomas is playing while his mother cooks) since they failed to interpret the knife that Thomas's mother was holding not as a representation of cooking, and viewed it as an expression of aggression towards Thomas' father, 
as noted by Participant B: "The mother is upset, wondering if the father will pick Thomas up, maybe she wants to kill him." All participants agreed that after the birthday, Thomas' father met Thomas, but they were not clear about the father arriving at the home, as emphasized by participant B "He sees his father's car arriving" and participant C "Waiting for his father to pick him up (Fig.3)". Participant $C$ assumes that "the father is coming to pick up Thomas to go somewhere."

Table 1: Results from specialist focus group 1 regarding the parts identified in the narrative.

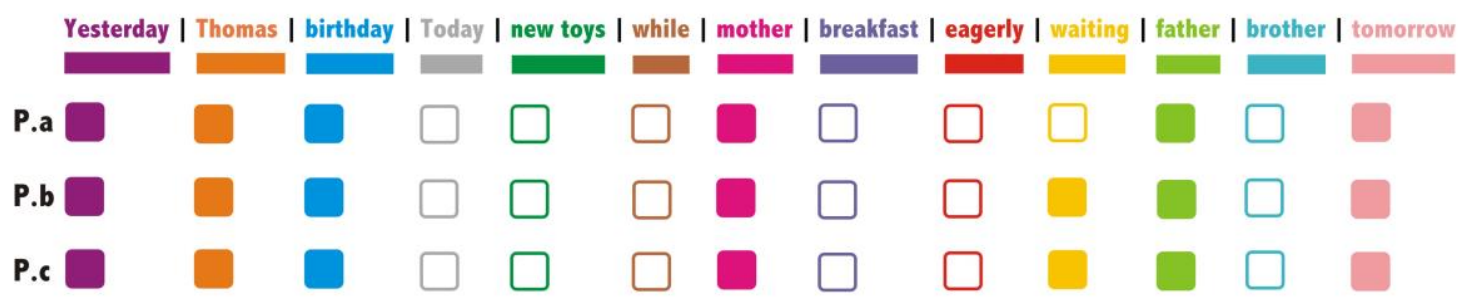

$\square$ Not Identified $\square$ Identified

At the end of each session they reported that they had understood the beginning, "It was Thomas' birthday. His father wasn't present, so he celebrated with his mother and friends, but spent the day missing his father and the next day he met his father. We do not agree with the end. Or maybe he goes to his father's home or his father is returning from a trip back home..." which was not so far from the initial narrative.

\section{Nonspecialist focus group 1}

With the same drawing panel, participants understood that there was a boy's birthday. Participant $\mathrm{C}$ did not understand the onomatopoeia drawn around Thomas's head in Fig.3, "A boy with these things on his head here and there." Indeed, these lines appeared three times: first, to identify Thomas' character in the birthday scene; when Thomas is playing, and also when the father and brother arrive home. In this drawing, the producer explained that the lines were just to create a graphic distinction between the character of Thomas and his brother. Participant B then suggested that the purpose of the lines was to show that Thomas was happy: "Maybe he's happy." The use of these schematic components were inconsistent throughout the drawings. They acquired several meanings but the same form was used for example, for both anxiety or happiness.

Figure 5: The character of Thomas in a drawing by a specialist / Session 3, and the mother's character in a drawing by a nonspecialist / Session 4.
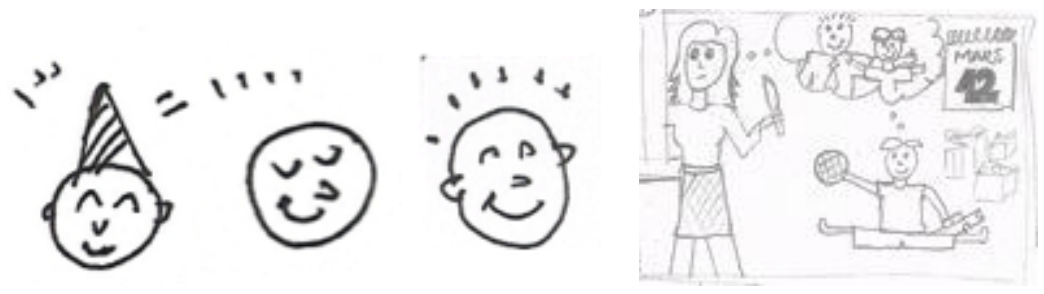

Participant $C$ understood that there were two different days in the narrative. Again, Thomas' brother was not identified because he appeared too similar to Thomas (Fig.4). The mother holding the knife was also observed by this group, including Participant B, "Here there's a knife too, right? (Fig. 2)." However, the participants did not associate it with the action of cooking. 
Table 2: Results from nonspecialist focus group 1 regarding the parts identified in the narrative.

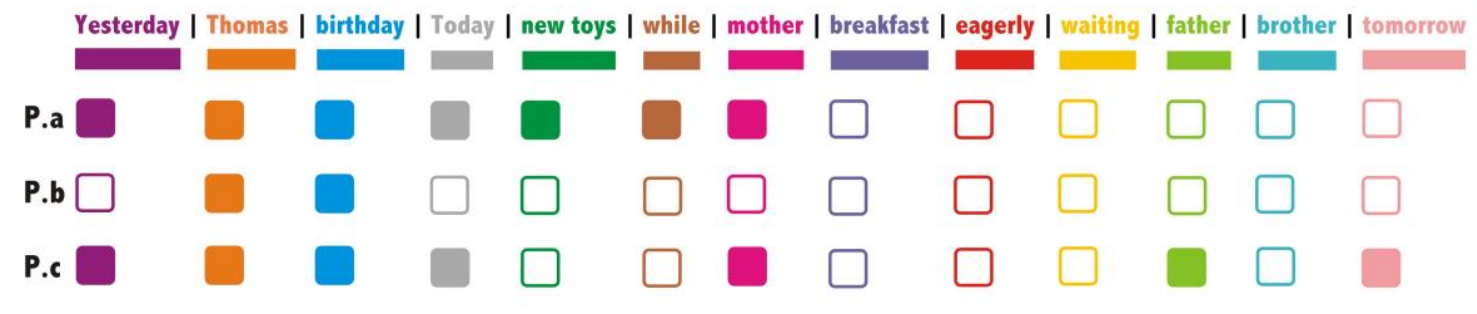

Not Identified $\square$ Identified

With regard to the temporal dimensions, Participant A believed that this narrative took place over two days, one day in the past when the birthday party took place, and another day in the future when Thomas was playing. He identified the simultaneous actions, even though the mother preparing breakfast was interpreted as the mother clearing up. Thomas sleeping to indicate the passage of time (one day to another), was interpreted as a nap. After Thomas played again it was not identified that it was his father who arrived, but rather Thomas who was going out somewhere.

According to participant $\mathrm{B}$, this all took place on one single day: "It's a kid's birthday party. I'm not sure if the party was during the day because there is a sun, but there is also a light bulb inside (Fig.1). This one is maybe not the mother (Fig.2/2nd box) it has a child's face. This character (the mother) is about to clean up the house after the party (Fig.2). And that character (the father) is either going or returning from somewhere (Fig.4)."

Participant C's version was, "I think this is the day of his birthday. He is very happy with his friends but only his mother was there. The next day his mother is cleaning the house (Fig.2) and wondering why the father did not go (Fig.4). The next day the boy is going somewhere with his father or he meets his father." This participant also understood the temporal dimensions of past, present and future. The representation of waiting was interpreted as the mother's thoughts regarding the absent father.

\section{Panel 2}

Figure 6 \& 7: Panel 2 compositions, drawing by Lille children - Session 2 and drawing by Parisian children -Session 3.
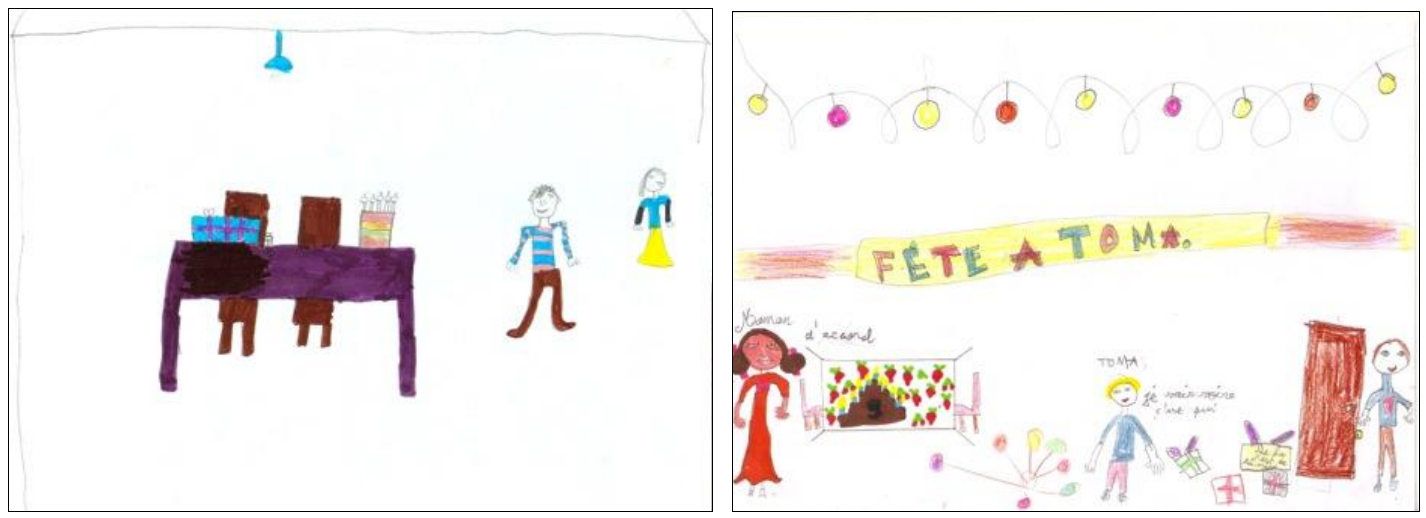

Anais [Oral] do $7^{\circ}$ Congresso Internacional de Design da Informação | CIDI 2015

Proceedings [Oral] of the 7th Information Design International Conference / IDIC 2015 
Figure 8 \& 9: Panel 2 compositions, drawing by nonspecialist - Session 1 drawing by specialist - Sessi

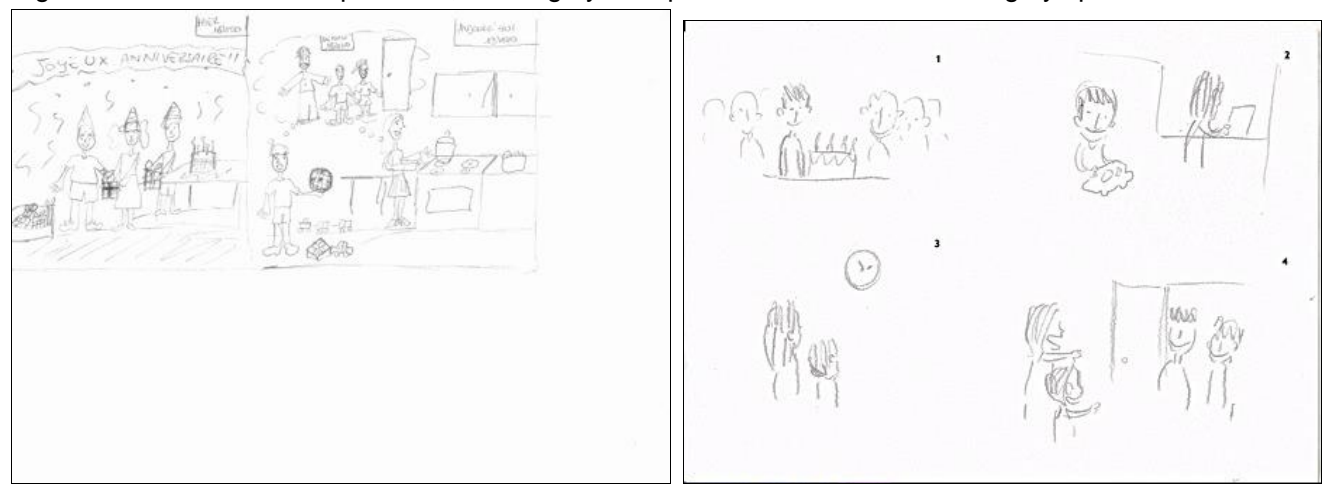

Specialist focus group 2

The session indicated that the birthday scene was well understood by all participants and that the references to time (yesterday, today, tomorrow) were only partly understood. Participants $A$ and $B$ identified that Thomas' birthday had been celebrated before, indicating the existence of a past time. For Participant $\mathrm{C}$, the birthday and all other events were taking place in the present. The participant who produced this drawing had written, "yesterday, today and tomorrow", in order to better explain to readers about the passing of time. The focus group participants did not fully consider the information.

With regard to the reading direction, especially in the drawing in Fig.9, participants initially read scenes 1-2-3-4 correctly. Afterwards, they were in doubt and opted for the reading direction 3-4-1-2. Participant B explained: "Ok, so the order is: they wait for the guests looking at the clock. The guests arrive, there's party and after he plays with his car (the toy)."

For participant A: "Thomas was celebrating his birthday, he was waiting for someone special (Fig.9). This person came, gave him a gift and the next day he returned to his everyday life, happy with his car (toy) and he was happy ever after ". Participant B said: "I think Thomas lives with his mother. He celebrated his birthday with friends and the next day his mother cooked (Fig.7). The father didn't know and was arriving, I'm not sure if it's the father (...)." And participant C said: "It's Thomas' birthday, he was waiting for the guests. The next day his mother was cooking, he has already opened the gifts thinking about the person who gave it to him (Fig.7). He lives alone with his mother. The father didn't appear in the drawing."

Table 3: Results from specialist focus group 2 regarding the parts identified in the narrative.

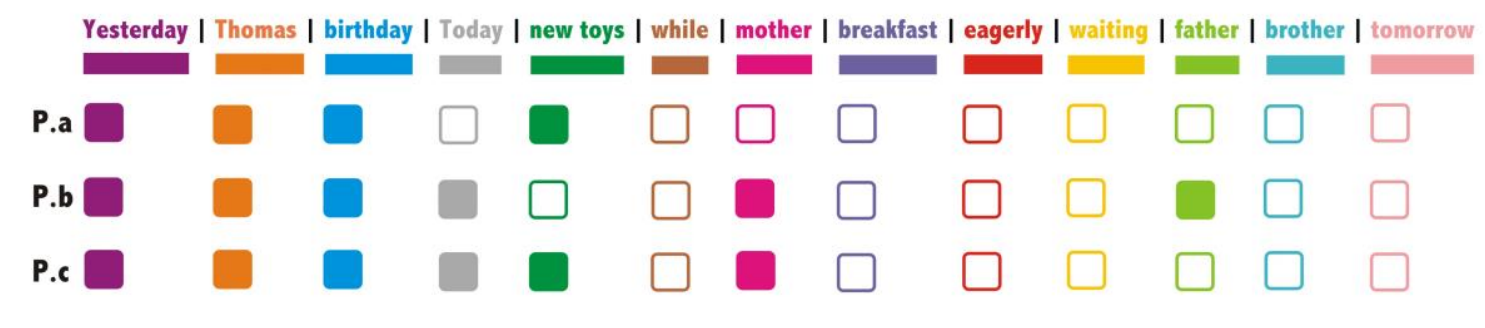

$\square$ Not Identified $\square$ Identified

Nonspecialist focus group 2

Anais [Oral] do 7º Congresso Internacional de Design da Informação | CIDI 2015

Proceedings [Oral] of the 7th Information Design International Conference / IDIC 2015 
Participants A, B and C identified the birthday and the past dimension. Participant $\mathrm{C}$ gave a version of the narrative: "Here, there are gift boxes, and tomorrow the gifts will be opened" based on the drawing by a nonspecialist (Fig.6), but in the end they only maintained the past. Following this, participants spent more than ten minutes without pursuing their discussion. Participant $C$ spoke and explained that "It's a birthday party, and it may be a surprise party, all the drawings show guests (Figs.6-8-9)."

Table 4: Results from nonspecialist focus group 2 regarding the parts identified in the narrative.

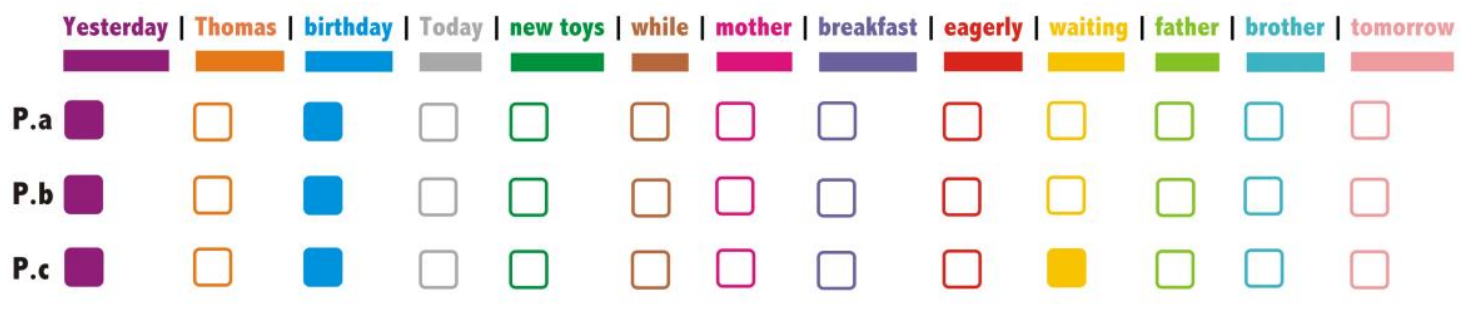

Not Identified Identified

\section{Panel 3}

Figure 10 \& 11. . Panel 3 composition, drawing by Lille children - Session 3 and drawing by Parisian children - Session 4 .

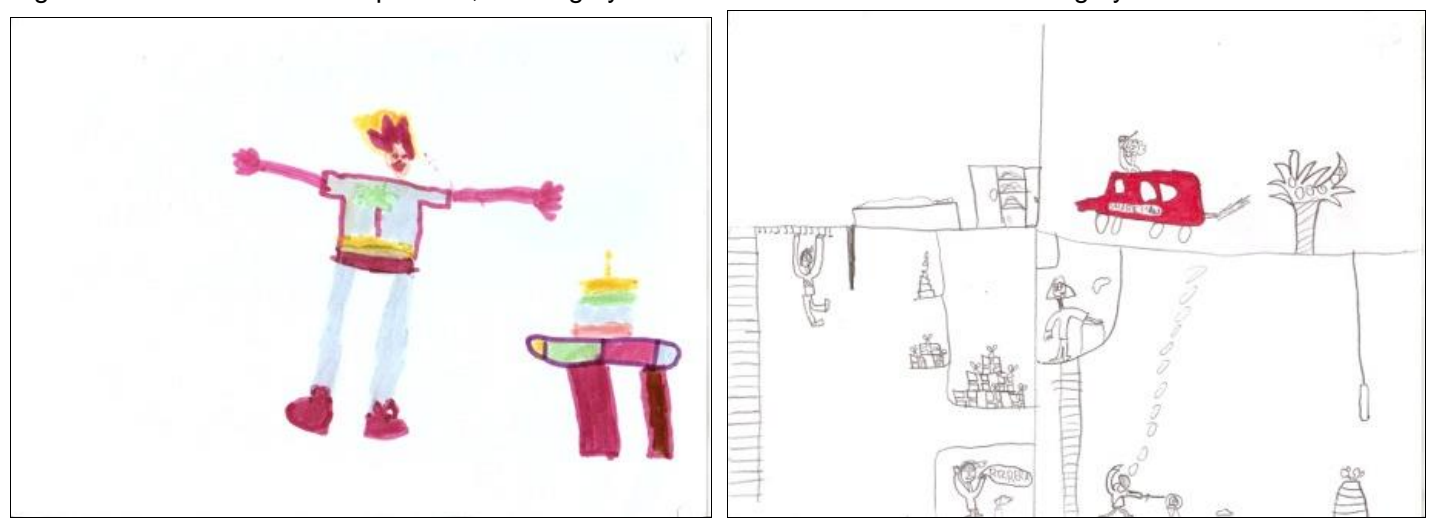

Figure 12 and 13. Panel 3 composition, drawing by specialist - Session 1 and drawing by nonspecialist - Session 2. 


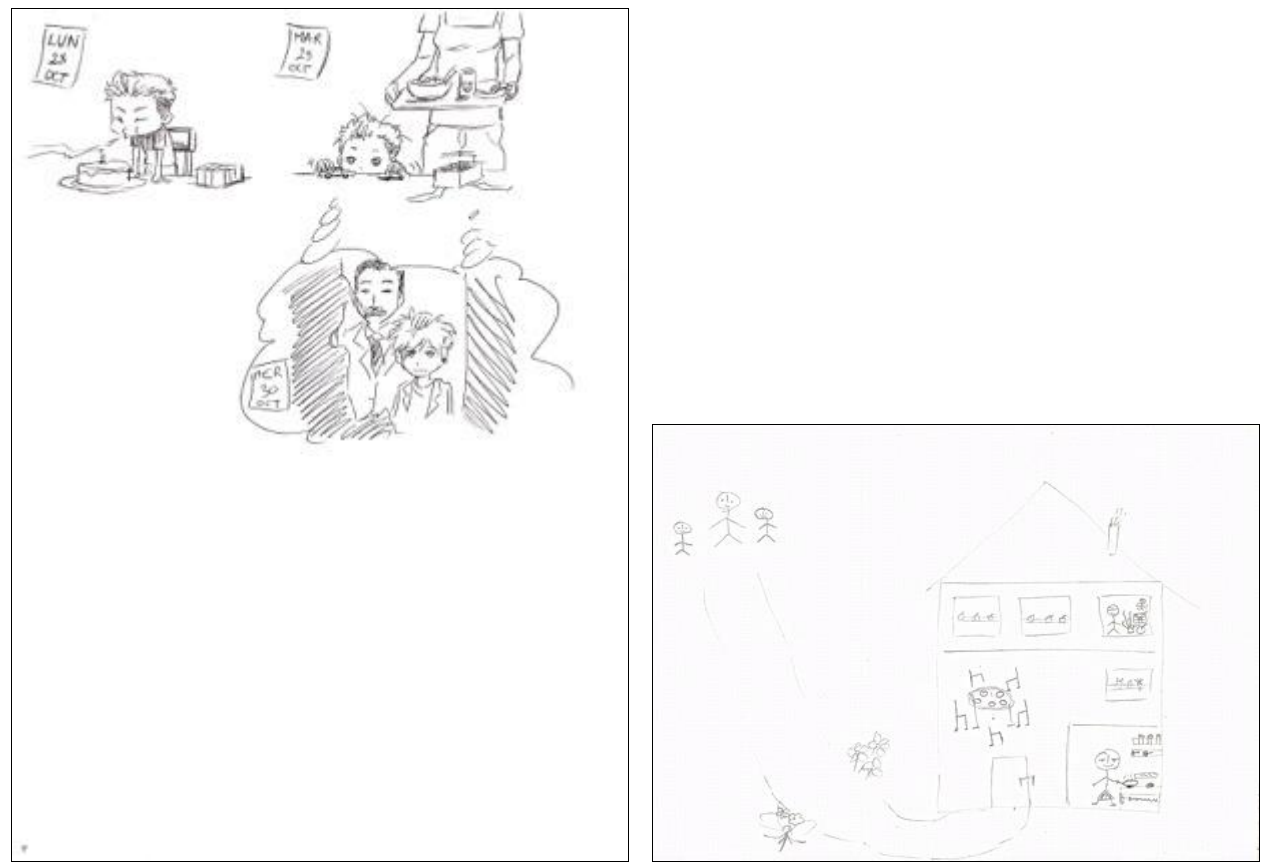

Specialist focus group 3

This session started with questions regarding the actions performed by the characters (cooking, playing). Participant B raised the issue of the time indicators: "Ah! I didn't notice that they had written Monday October 28th, Tuesday October 29th and Wednesday October 30th (Fig.10)." This intervention created a new interpretative path that included issues of temporality. The participants engaged in a number of interpretative proposals to integrate time with the described actions. Participant $C$ said, "There's a birthday and the next day he plays and thinks about a man who's going to arrive (Fig.10)." This proposal developed and for Participant A this man became Thomas' father: "Ah! I know! It is only the day after his birthday and he is thinking about how the future will be with his father (Fig.10) ... I do not know ...", and for Participant C: "This is a door and him arriving with his father (Fig.10)."

For a while the participants tried to understand the identity of the adult male character and his relationship with the boy who was having a birthday party. Participant $C$ proposed, for example, that it was a visit, or a birthday with gifts (Fig.13). Participant B suggested the possibility that the character was imagining the near future: "He imagines someone arriving (Fig.13)" and Participant A continued: "He imagines how his life would be with his father (Fig.13)."

Participants did not understand the representation of Thomas and his brother and asked questions to determine if the character was supposed to represent Thomas' brother, or an older version of Thomas, or indeed another person. Participant $C$ asked: "Why does he have earrings and a goatee ?" According to Participant A (Fig.10) the character corresponded to an older version of Thomas. Participant $B$ noted that the speech balloon where the unknown character appears next to the father came not only from Thomas but also from his mother. Finally, the participants presented a common version: "He celebrated his birthday on October 28th without his father and brother. The next day he is playing with the gift he received and his mother was there. And with his mother, he imagines the arrival of his father and brother who were not there."

Table 5. Results from specialist focus group 3 regarding the parts identified in the narrative. 


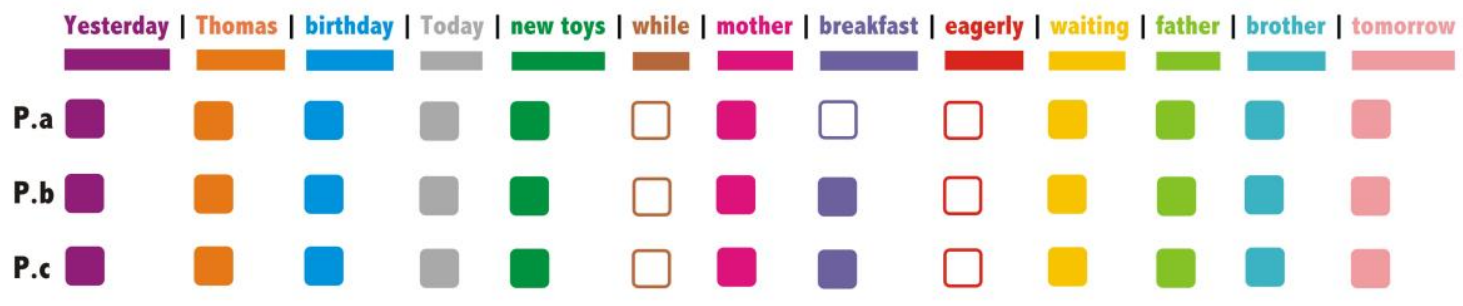

$\square$ Not Identified $\square$ Identified

Nonspecialist focus group 3

The nonspecialists started by identifying Thomas, the mother and the birthday party (Participants $A$ and $B$ ) based on Figures 11 and 13.

Participant $B$ had doubts about the reading direction of Figure 13. This drawing produced by a Parisian child, is distinctive in that it has four frames in terms of spatial organization, but functionally there are only three, since two boxes were merged. The first frame takes half the page on the left, but it is divided into two parts to make a frame. In the top left there is the room and on the bottom left, the living room is separated by a line, which is a wall, as stated by the producer: "There is a room, a wall and there is the living room (participant producer Parisian children - Session 4)."

Firstly, Participant $C$ read the third frame, then the second and finally, the first. This sense of reading is quite specific and does not fit in with the Western reading conventions where the boxes should be read from left to right and from top to bottom. According to Participant C: "There is the mother who arrives back home from work. She prepares things, and he (Thomas) is in his room playing (Fig.13)."

Figure 14. Reading directions, drawing by Parisian children - Session 4.

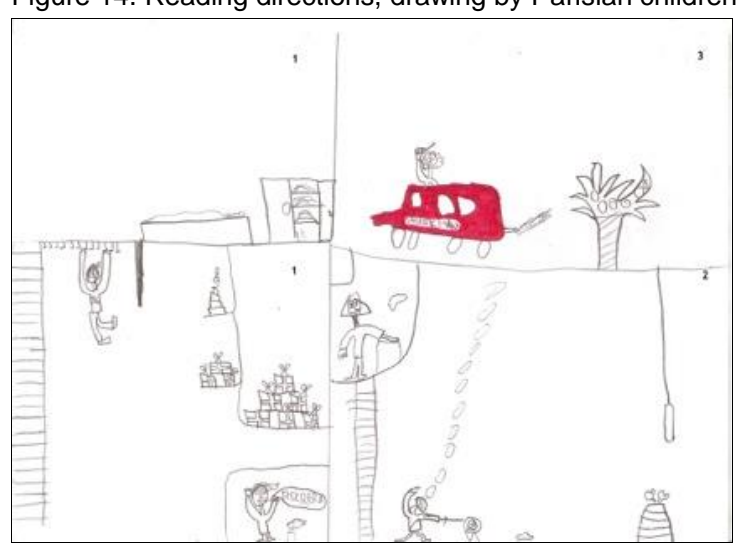

For Participant A: "There is a birthday party in all the drawings, we can see the birthday party clearly (Fig.12). Here we see the birthday party and the next day he won't eat, he was afraid and hid (Thomas, Fig.10). Here we see him playing (Thomas) and the mother returns from work (Fig.13), he thinks it's a thought balloon, right? He celebrated his birthday and he plays with his new gift."

Participant $B$ added the possibility that Thomas was thinking about his father, who did not go to his birthday (Fig.10). Participant $C$ assumed that friends had come for the birthday (Fig.11). Participant A then proposed: "This is the birthday party of a child, he is happy because he is celebrating, and the next day he has no appetite (Fig.10)". According to the producers, Thomas was sad, but readers misunderstood the child's sadness for having no appetite or not wanting to eat.

Anais [Oral] do 7º Congresso Internacional de Design da Informação | CIDI 2015

Proceedings [Oral] of the 7th Information Design International Conference / IDIC 2015 
Table 6: Results from nonspecialist focus group 3 regarding the parts identified in the narrative.

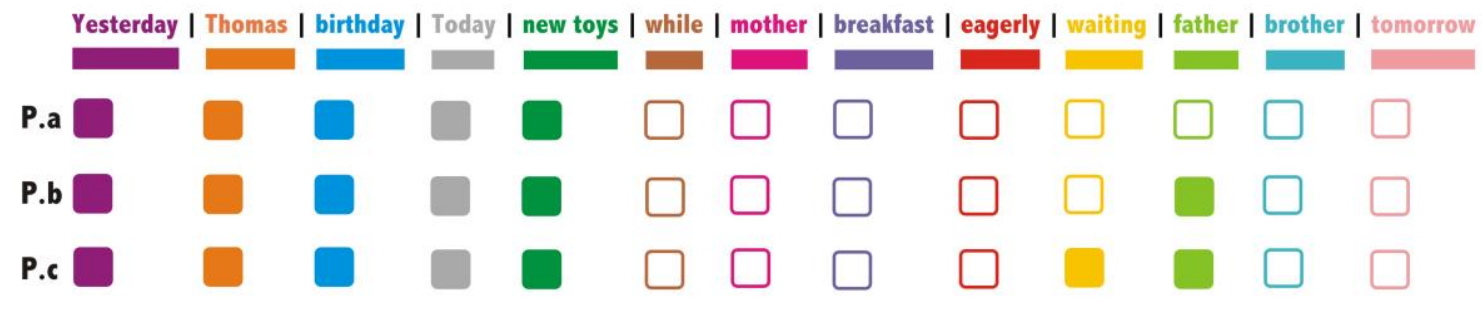

$\square$ Not Identified $\square$ Identified

\section{Panel 4}

Figure 15\& 16. Panel 4 composition, drawing by Lille children - Session 4 and drawing by Parisian children - Session 1.

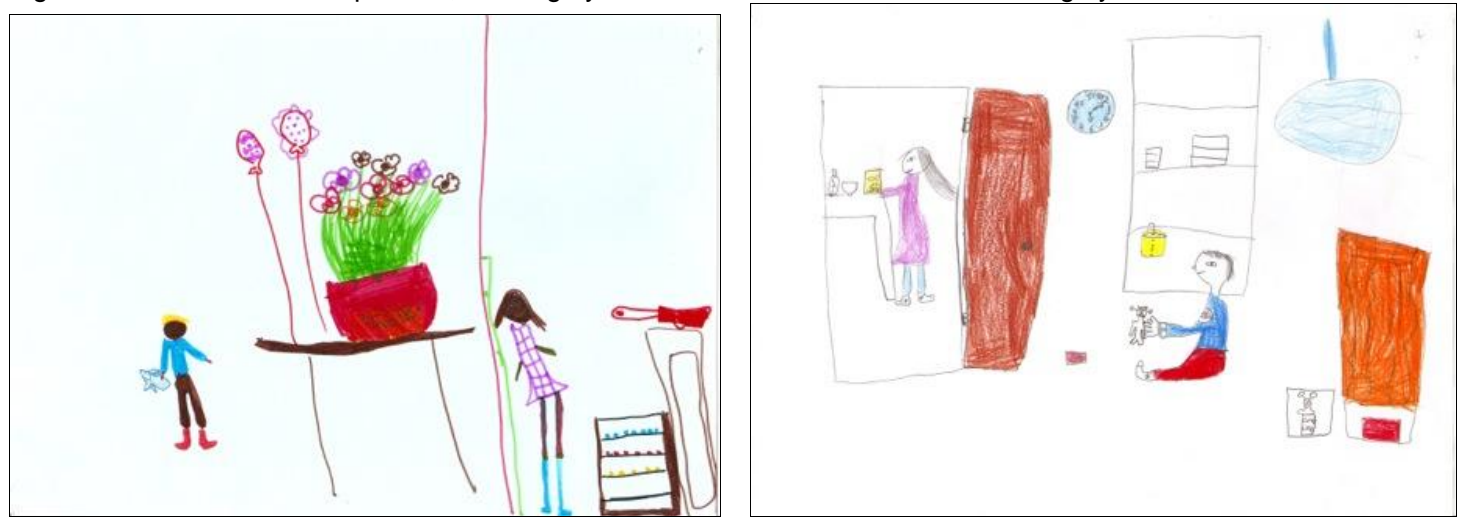

Figure 17 \& 18. Panel 4 composition, drawing by specialist - Session 2 and drawing by nonspecialist - Session 3. 

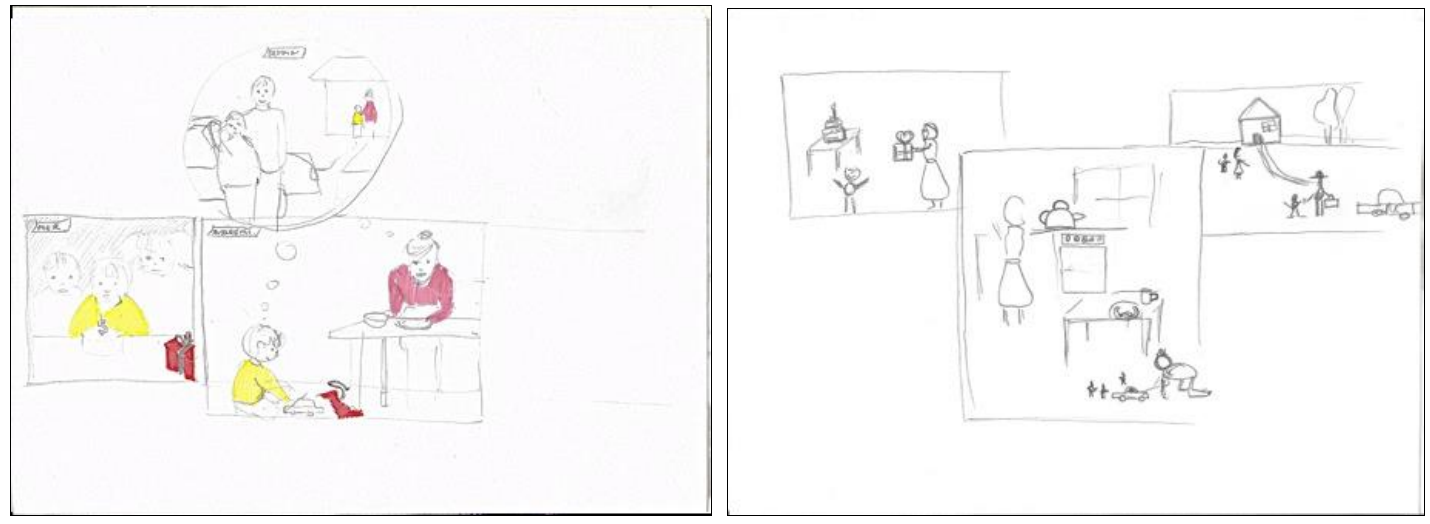

Specialist focus group 4

Specialists began by identifying the birthday. Participant A noted the fact that in the four drawings the mother was preparing something to eat. Participants $B$ and $C$ indicated the presence of the father (Figs.16, 17). Participant B attempted to identify temporal dimensions: "Yesterday was the birthday, today he is playing alone and he knows that tomorrow he will go somewhere with the others (Fig. 16)."

At the end of discussions, participants reached a consensus and suggested this narrative version: "There was a boy who celebrated his birthday." Participant A added: "His parents were divorced" and according to participant C: "He is playing alone. There are people next to him, but nobody cares or plays with the boy..." which allowed Participant A to say that it was "because the boy's parents were divorced."

Table 7. Results from specialist focus group 4 regarding the parts identified in the narrative.

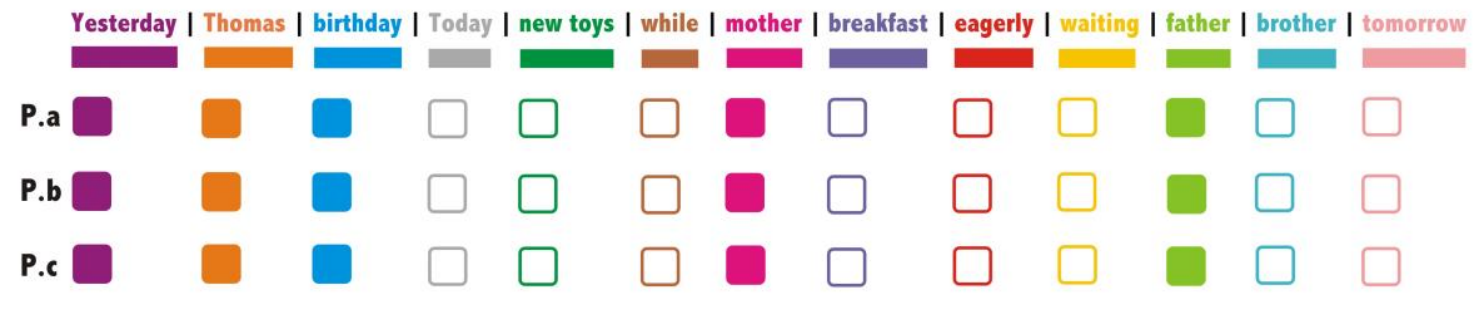

\section{Not Identified $\square$ Identified}

Nonspecialist focus group 4

According to Participant A in Figure 17: "Maybe it is the past, present and future of a family." Participant $\mathrm{C}$ added that it was perhaps "the father or the son" and Participant A said it was perhaps "someone's childhood ... someone talking to his son ... like memories."

Participants proposed the following narrative: "Once upon a time there was a mother who was cooking while her son played, she gave him a gift while he was playing at school (Fig.17), or it's a house, a mother with her son, a father who went to work and left the son at school, while the mother stays at home with the son, the father goes to work, the mother stays at home with her son playing."

On observing their disagreement, we intervened, proposing that they discussed a little more in order to either produce a common version or an individual's version. Participant B suggested: "Once upon a time there was a child, while the mother was cooking he played with his toys" and Participant $\mathrm{C}$ added: "While his father was at work", but Participant B still disagreed.

Table 8. Results from nonspecialist focus group 4 regarding the parts identified in the narrative. 


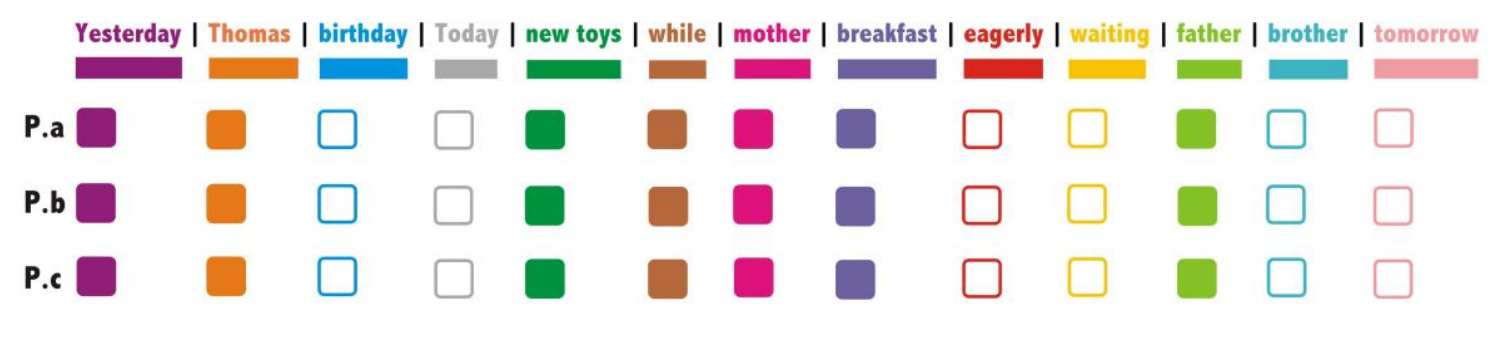

Not Identified $\square$ Identified

\section{Conclusions}

During the focus group sessions, participants mostly initiated their narrative process by correctly identifying the elements and temporal dimensions. However, as the discussions progressed in the search for a mutual coherent interpretative path, each participant began to contribute with her/his understanding or experience, and thus opinions would begin to change. At this point they would discard or discredit certain elements. Although all the dialogues were analysed, we only considered the final versions presented by the participants. These versions were often less precise or rich in detail than the discussions that took place during the process.

We observed that each producer group presented different strategies when drawing. The specialist group, with their knowledge of managing spatial organization and using schematic components and onomatopoeias, produced very synthetic drawings. Their drawing skills became a handicap for readers (specialists and nonspecialists) who encountered many difficulties in comprehending the functions of isolated components and the relationships between components. In this sense, the drawings produced by the Parisian children and the nonspecialists demonstrated greater communicational potential, even though they had little previous experience of drawing. Their drawings were more redundant, but provided more help to readers by employing a combination of pictorial and textual elements as a manner to reinforce the message (Eysenck, 1988; Lowe 1993; Wogalter et al., 1997; Sadoski, 1999; Wright, 1999a, 1999b; Maia, 2008; Miranda, 2013). The Lille children demonstrated a very illustrational approach, and their drawings did not help readers to understand the initial narrative.

Although the temporal dimensions were poorly understood, they were more understandable when the information was presented in boxes, thus separating and providing autonomy to portions of the overall sequence. Reading directions were also problematic for both specialists and nonspecialists. When portions of sequence were aligned horizontally reading was made easier, but when they were superimposed onto one another or created in lines, participants hesitated when reading these columns or lines. The use of arrows and numbers helped to indicate direction, and the use of boxes ensured that readers understood the portions of information. Onomatopoeias and balloons on the other hand, created reading problems because their use was inconsistent. Simultaneous actions were understood as 'and' instead of 'while'. Since the specialists are specialized in producing, this in turn influences the reading process, which is also specialized (Coutinho, 1998; Twyman, 1985; Dondis, 1997; Trumbo, 1999; Seels, 1994 and Miranda, 2004, 2006)

With regard to the production efforts of the four groups, our data indicates that designers underestimate the comprehension capacity of readers. In our experiment, designers (specialists) were also less inclined to rethink their strategies, which would explain why the most successful drawings for the focus group readers appeared in the following order: nonspecialists, Parisian children, specialists and Lille children. Even if it is not possible to generalise our results, the experiment nonetheless presents a number of useful guidelines for producing sequential

Anais [Oral] do $7^{\circ}$ Congresso Internacional de Design da Informação | CIDI 2015

Proceedings [Oral] of the 7th Information Design International Conference / IDIC 2015 
narratives, as well as important considerations on the role played by design education, so that future designers may integrate the user in an effort to reach them more efficiently.

\section{Referências}

COOK, B. (1981). Understanding pictures in Papua New Guinea. Elgin, III., U.S.A: D.C. Cook Foundation.

COUTINHO, S. G. (1998). Towards a methodology for studying commonalities in the drawing process of young children. v.1. Thesis unpublished (Doctorat en Tipographie et Communication) - Department of Typography \& Graphic Communication, The University of Reading, England.

DONDIS, D. A. 1997. Sintaxe da linguagem visual. 2. ed. São Paulo: Martins Fontes.

EYSENCK, M. W. 1988. A handbook of cognitive psychology. Londres : Lawrence Erlbaum Associates.

GROENSTEEN, T. 1999. Système de la bande dessinée. Paris : Presses universitaires de France, coll. Formes sémiotiques.

LOWE, R. K. 1993. Diagrammatic information : techniques for exploring its mental representation and processing. Information Design Journal, 7(1), 3-17.

MAIA, T. C. 2008. A representação de dimensões de tempo em instruções visuais e sua relação com imagens mentais de usuários. Dissertação (Mestrado) unpublished, Departamento

MIRANDA, E. R. 2004. Desenho de memória $x$ desenho com estimulação da imagem mental: um estudo. Monografia (License) unpublishes, Departamento de Design, Universidade Federal de Pernambuco, Brazil.

MIRANDA, E. R. 2006. As crianças e os adultos como originadores de Artefatos Gráficos Comunicacionais: em busca de um modelo de análise. Dissertação (Master) unpublished, Departamento de Design, Universidade Federal de Pernambuco, Brazil.

MIRANDA, E. R.2013. Étude de la production et de la lecture des Artefacts Graphiques Communicationnels en Séquence par les enfants et les adultes spécialistes et nonspécialistes. Approche cognitive et Design de l'Information. Thèse (doctorat) unpublished, Arts \& Sciences de l'Art, Spécialité Design, Université Paris I Panthéon-Sorbonne.

SADOSKI, M. 1999. Theoretical, empirical and practical considerations in designing informational text. Document design, 1(1), 25-34.

SELLS, B. 1994. Visual Literacy: the definition problem. Moore and Dwyer (Eds.) London.

TRUMBO, J. 1999. Visual literacy and science communication. Science Communication, v. 20, n. 4, p. $409-425$.

TWYMAN, M. L. 1985. Using pictorial language: a discussion of the dimensions. In: Dufty, T. M. \& Waller, R. (Eds.) Designing usable text. Orlando, Florida: Academic Press, p.245-312.

WOGALTER, M. S., SOJOURNER, R. J., BRELSFORD, J. W. 1997. Comprehension and retention of safety pictorials. Ergonomics, 40(5), 531-542.

WRIGHT, P. 1999a. Comprehension of printed instructions: examples from health materials. In D. Wagner, R. Venezky, \& B. Street (Eds.) Literacy: an international handbook. Boulder, CO: Westview Press, p.192-198.

WRIGHT, P. 1999b. Printed instructions: can research make a difference? In H. J. G. Zwaga, T.

Anais [Oral] do 7º Congresso Internacional de Design da Informação | CIDI 2015

Proceedings [Oral] of the 7th Information Design International Conference / IDIC 2015 
Boersema, H. C. M. Hoonhout (Eds.) Visual Information for everyday use: design and research perspectives. Londres: Taylor \& Francis, p.45-67.

\section{Sobre os autores}

Eva Rolim Miranda, UFPE, Brasil <evarolim@gmail.com> 